\title{
Thorium and Uranium distribution in a passive system for mine water treatment
}

\author{
Maria Isabel Prudêncio, ${ }^{1, *}$, Teresa Valente ${ }^{2}$, Rosa Marques $^{1}$, Maria Amália Sequeira \\ Braga $^{2}$, and Jorge Pamplona ${ }^{1}$ \\ ${ }^{1}$ Centro de Ciências e Tecnologias Nucleares (C2TN), DECN, Instituto Superior Técnico, \\ Universidade de Lisboa, Estrada Nacional 10 (km 139.7), 2695-066 Bobadela, Portugal \\ ${ }^{2}$ Institute of Earth Sciences (ICT), Pole of the University of Minho, Campus de Gualtar, 4710-057 \\ Braga, Portugal
}

\begin{abstract}
The abandoned Jales mining area is a sulphide-rich deposit (Northeast of Portugal). Acid mine drainage resulted from oxidation of sulphides is treated in a passive system with wetlands. The present work studies the thorium and uranium behaviour in the water and in the fine fractions of wetland soils throughout the passive treatment system. The evaluation of the efficiency of the all system was done determining metals concentration variation in the creek water upstream and downstream of the treated effluent discharge. The results point to higher efficiency to retain Th after summer than after winter. The opposite was found for uranium, which increases significantly in the creek water after summer and, in a lower extent, after winter. Also, Th and $U$ have a tendency to increase in the fine fractions of the wetlands soils after summer, which can be explained by the longer water-soil contact/lower water dynamics. Nevertheless uranium has a much higher tendency to be in solution as revealed by a high concentration in the porewater of wetland soils. A relation of these actinides behaviour with the $\mathrm{Fe}$ and $\mathrm{Mn}$ distribution is not clear.
\end{abstract}

\section{Introduction}

As a consequence of sulfide oxidation in mines, dumps and tailings impoundments, acid mine drainage (AMD) poses often long-term threat to the aquatic environment. To deal with this type of contamination, passive systems with wetlands have been widely used in legacy mining sites [1].

The abandoned Jales mining area is a sulphide-rich deposit located in the Northeast of Portugal. The paragensis is not very diverse, with dominance of host rock minerals (quartz, plagioclase and micas) and the sulphides arsenopyrite, chalcopyrite, galena, sphalerite and phyrrhotite. Mining activities were performed in an uncontrolled way, originating erosion and serious environmental contamination, namely related with AMD processes. A rehabilitation project has been implemented including procedures for closing mine adits and shafts, measures for containing mine wastes and bioremediation; a passive system was built to collect and treat the drainage that flows from an old adit into the Peliteira creek [2].

\footnotetext{
*Corresponding author: iprudenc@ctn.tecnico.ulisboa.pt
} 
Previous studies on the role of mineralogical attenuation for metallic remediation in this passive system showed that $\mathrm{Fe}, \mathrm{As}, \mathrm{Ba}, \mathrm{Co}, \mathrm{Mn}$ and $\mathrm{Zn}$ are mainly controlled by iron oxides and clay minerals among other phases, and how the REE fractionation occurring along passive treatment systems can be used as tracers to follow up and understand the geochemical processes that promote the remediation of AMD [3-5]. In this work special attention is provided to actinides $(\mathrm{U}, \mathrm{Th})$ behaviour, and their relation with $\mathrm{Fe}$ and $\mathrm{Mn}$ distribution, in the course of the passive treatment system constructed for AMD treatment in Jales mine.

\section{Site description and methods}

Jales mining site is an inactive gold mining area located in the Vila Real district, in the Northeast of Portugal (Fig.1). The climate is temperate warm with highest rainfall values in winter (mainly in January), being July the driest month. The average annual temperature and rainfall are $12.5^{\circ} \mathrm{C}$ and $1214 \mathrm{~mm}$, respectively. The mine water can be generically described as an acid $(\mathrm{pH}<4.5)$ and sulphate-rich solution. The mouth of the mine was littered with limestone. After this first contact with limestone, follows an open limestone system devoted to chemical processes, especially oxidation and neutralization, comprising a reception basin (of which the bottom is filled with limestone), a cascade aeration facility and a limestone channel (inorganic stage). This pre-treated effluent enters into typical aerobic wetlands. The all system promotes oxygenation, $\mathrm{pH}$ raise, alkalinity increase and subsequent precipitation of metals. References and description of the sampling sites of water and soils of the wetlands are given in Tables 1 and 2 .

Chemical contents in water were obtained by inductively coupled plasma optical emission spectrometry and mass spectrometry (ICP-OES, ICP-MS) at the Actlabs, in Canada, and in the wetland soils by instrumental neutron activation analysis (INAA) [6,7]. Chemical analyses were performed on two size fractions: $<20 \mu \mathrm{m}$ obtained by wet sieving and $<2 \mu \mathrm{m}$ obtained by sedimentation based on the Stoke's law [8].

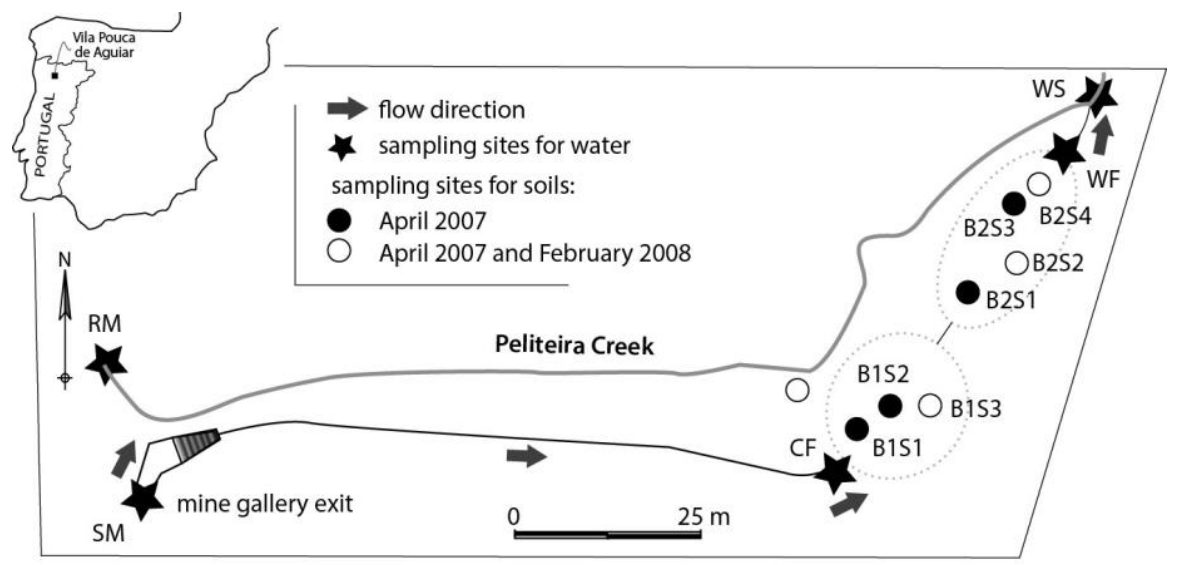

Fig. 1. Location map of the Jales mining site, including the layout of the water treatment plant, and the indication of the sampling sites (adapted from [4]). 


\section{Results and discussion}

The variation in the concentrations of $\mathrm{Th}, \mathrm{U}, \mathrm{Fe}$, and $\mathrm{Mn}$ in the water along the passive system, after summer and after winter, and the influence of the effluent discharge in the water of the Peliteira creek are shown in Fig. 2. The contents of the elements are given in Table 1. Uranium and thorium concentrations in the $<20 \mu \mathrm{m}$ fraction and $<2 \mu \mathrm{m}$ fraction of the wetland soils, and in the whole sample ( $<2 \mathrm{~mm}$ fraction) of the soil of the wetlands, are given in Table 2 and are represented graphically in Fig. 3.

Table 1. Water data from the Jales mining site and the passive treatment system: description of the sampling site, month and year of collection in the reference samples and chemical contents $(\mu \mathrm{g} / \mathrm{L})$.

\begin{tabular}{|c|c|c|c|c|c|c|}
\hline & Description & Reference & $\mathbf{U}$ & Th & $\mathbf{F e}$ & Mn \\
\hline \multirow{5}{*}{ 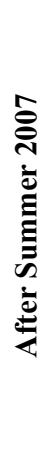 } & $\begin{array}{l}\text { Peliteira creek } \\
\text { upstream }\end{array}$ & $\mathrm{RM} / 08 / 07$ & 0.001 & 0.001 & 10 & 0.1 \\
\hline & $\begin{array}{l}\text { Outflow of the } \\
\text { littered adit mouth }\end{array}$ & $\mathrm{SM} / 08 / 07$ & 0.839 & 0.016 & $<10000$ & 2520 \\
\hline & $\begin{array}{l}\text { Exit of the limestone } \\
\text { channel }\end{array}$ & $\mathrm{CF} / 08 / 07$ & 0.478 & 0.003 & 3790 & 2380 \\
\hline & Exit of wetland 2 & $\mathrm{WF} / 08 / 07$ & 0.512 & $<0.001$ & $<10$ & 3870 \\
\hline & $\begin{array}{l}\text { Peliteira creek after } \\
\text { effluent discharge }\end{array}$ & $\mathrm{WS} / 08 / 07$ & 0.195 & $<0.001$ & 20 & 2710 \\
\hline \multirow{7}{*}{ 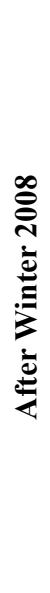 } & $\begin{array}{c}\text { Peliteira creek } \\
\text { upstream }\end{array}$ & $\mathrm{RM} / 02 / 08$ & 0.019 & $<0.001$ & 40 & 21.3 \\
\hline & $\begin{array}{l}\text { Outflow of the } \\
\text { littered adit mouth }\end{array}$ & $\mathrm{SM} / 02 / 08$ & 0.844 & 0.017 & 44500 & 2210 \\
\hline & $\begin{array}{l}\text { Exit of the limestone } \\
\text { channel }\end{array}$ & $\mathrm{CF} / 02 / 08$ & 0.269 & 0.005 & 16400 & 2290 \\
\hline & Exit of wetland 2 & $\mathrm{WF} / 02 / 08$ & 0.141 & 0.003 & 5820 & 2400 \\
\hline & $\begin{array}{l}\text { Peliteira creek after } \\
\text { effluent discharge }\end{array}$ & $\mathrm{WS} / 02 / 08$ & 0.07 & 0.004 & 3200 & 1940 \\
\hline & $\begin{array}{c}\text { Porewater of soil in } \\
\text { wetland } 1\end{array}$ & PWB1S3 & 18.1 & 0.003 & 190 & 44400 \\
\hline & $\begin{array}{c}\text { Porewater of soil in } \\
\text { wetland } 2\end{array}$ & PWB2S4 & 0.032 & 0.012 & 400 & 2680 \\
\hline
\end{tabular}

In general, higher chemical variations in the water are found after summer. In this situation of low water dynamics, the passive treatment system is efficient to retain $\mathrm{Th}$ in both AMD-limestone interaction part and wetlands (Fig. 2A), probably by adsorption from aqueous solution by clay minerals and other secondary phases. This is in agreement with the concentration of Th in the fine fractions of the wetland soils (Fig. 3). Accordingly, Th concentration does not vary significantly in the creek water after discharge of the treated effluent. Uranium appears to be also retained, but not enough to avoid its significant increase in the water creek (Fig. 2A). This difference relative to Th agrees with the lower U concentration in the fine fractions relative to the whole sample of the wetland soils (Fig. 3), indicating a higher $U$ mobility. The exposure of rocks to AMD in waste piles and underground mines may release significant quantities of $U$ to the environment in different 
ionic forms [9]. A non-conservative behaviour of this element has also been found in other environments conditioned by AMD in SW Spain [10].

After winter, Th and $U$ (and also Fe) contents variation in the water across the system show a similar trend. Uranium is more concentrated than $\mathrm{Th}$ as found after summer. Manganese behaviour appears to be similar in the two seasons, being in solution rather than precipitating. This trend agrees with the high concentration of $\mathrm{Mn}$ in the porewater of soil in the wetlands samples, particularly in wetland 1 (Table 1), and in the creek water after the effluent discharge (Fig. 2B).

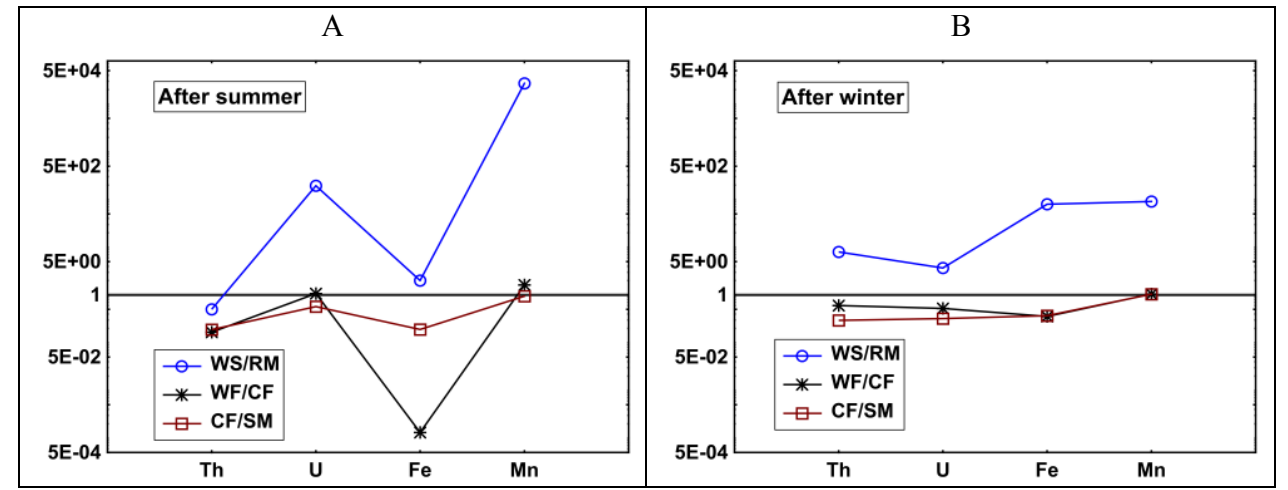

Fig. 2. $U$ and Th variations in the water in the Peliteira creek (RM) and the treatment system of the Jales mining area (northeast of Portugal) after summer 2007 (A) and after winter 2008 (B) (analytical results less than the detection limit were assumed as $2 \mathrm{x}$ for the graphs and trend evaluation) ( $\mathrm{Fe}$ and Mn data from [3]).

Table 2. Uranium and thorium concentrations $(\mathrm{mg} / \mathrm{kg})$ in the $<20 \mu \mathrm{m}$ fraction and $<2 \mu \mathrm{m}$ fraction of the wetland soils of the passive system of an abandoned mine (Jales, Portugal), and in the whole sample $(<2 \mathrm{~mm}$ fraction) of the soil used in the wetlands.

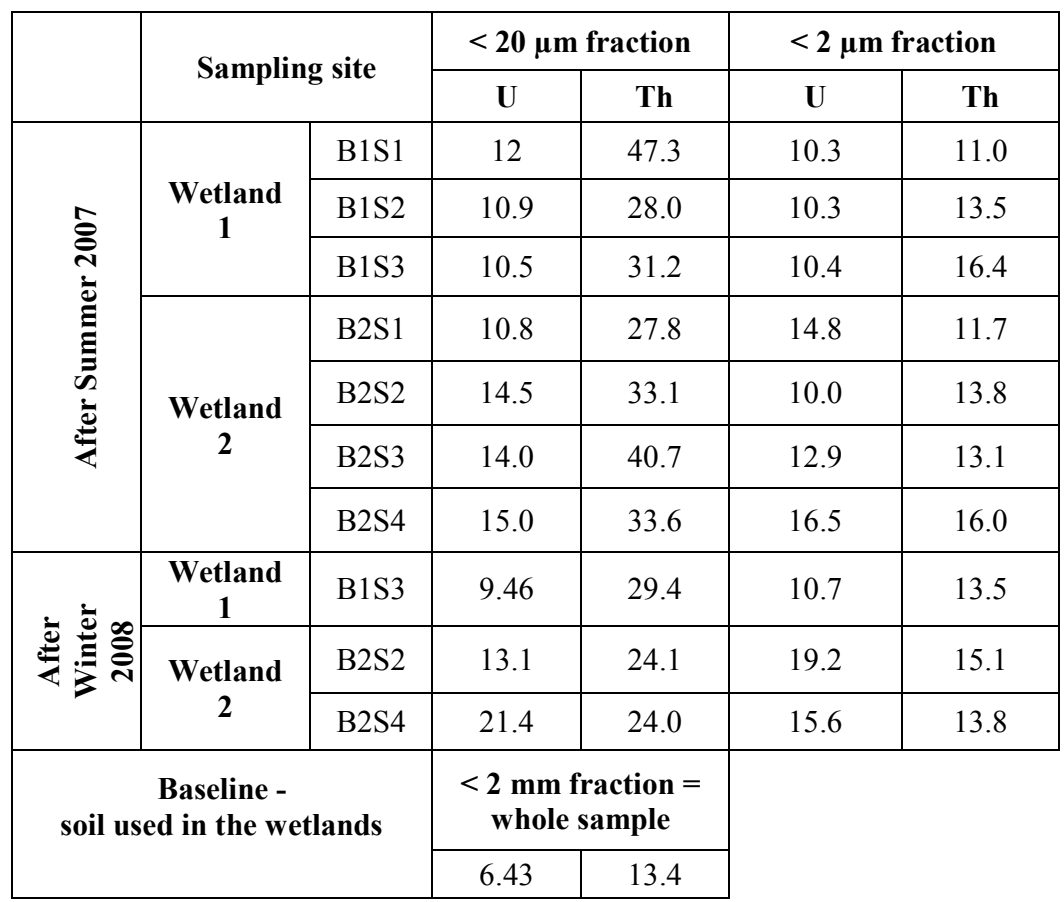


The high concentration of $\mathrm{Fe}$ found after summer in the $<2 \mu \mathrm{m}$ fraction of the wetland soils, particularly at the entrance of wetland 2 (Fig. 3B), can be explained by the incorporation of the ochre precipitates resulting from the AMD-limestone interaction during this period of low water dynamics.

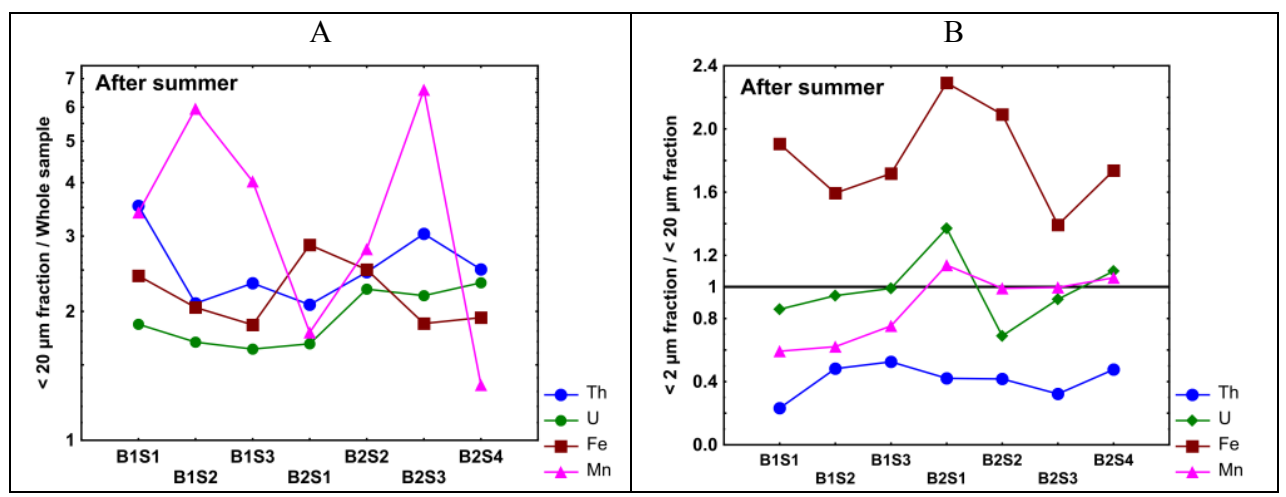

Fig. 3. $U$ and $T h$ variations in the $<20 \mu \mathrm{m}$ fraction relative to the whole sample (A) and in the $<2 \mu \mathrm{m}$ fraction relative to the respective $<20 \mu \mathrm{m}$ fraction (B) of the soils of both wetlands.

Thus, the passive treatment system of the Jales mining area showed a higher efficiency to retain Th after summer than after winter. The opposite was found for uranium, which increases significantly in the creek water after summer and, in a lower extent, after winter. The relation of these actinides studied with the $\mathrm{Fe}$ and $\mathrm{Mn}$ distribution is not clear. Further detailed studies are foreseen to better evaluate the role of iron and manganese oxides and other phases in the fixation of these metals in passive treatment systems.

Thanks are given to EDM, S.A. for providing access to the water treatment plant, FCT (Portuguese Science and Technology Foundation, UID/Multi/04349/2013, and COMPETE 2020 (Programa Operacional da Competitividade e Internacionalização), project ICT (UID/GEO/04683/2013) with reference POCI-01-0145-FEDER-007690 and project Nano-MINENV number 029259.

\section{References}

1. J. Skousen, C.E. Zipper, A. Rose, P.F. Ziemkiewicz1, R. Nairn, L.M. McDonald, R.L. Kleinmann, Mine Water Environ 36,133-153 (2017)

2. EDM. Recuperacão ambiental da escombreira da mina de Jales. EDM SA, (2006)

3. T.M. Valente, M. Antunes, M.A. Sequeira Braga, M.I. Prudêncio, R. Marques, J. Pamplona, Earth Sci. 66, 1, 39-54 (2012)

4. M.I. Prudêncio, T.M. Valente, R. Marques, M.A. Sequeira Braga, J. Pamplona, Chemosphere 138, 691-700 (2015)

5. M.I. Prudêncio, T.M. Valente, R. Marques, M.A. Sequeira Braga, J. Pamplona, Procedia Earth Planet. Sci. 17, 932-935 (2017)

6. E. Martinho, M.A. Gouveia, M.I. Prudêncio, M.F. Reis, J.M.P. Cabral, Appl. Radiat. Isot. 42, 11, 1067-1071 (1991)

7. R. Marques, J.C. Waerenborgh, M.I. Prudêncio, M.I. Dias, F. Rocha, E. Ferreira da Silva, Catena 113, 95-106 (2014)

8. G.W. Brindley, G. Brown, Crystal structures of clay minerals and their $x$-ray identification (Mineralogical Society, Monograph 5, London, 1980)

9. J.S. España, International Conference Uranium biogeochemistry, Switzerland (2018) 
10. A. Hierro, J.E. Martín, M. Olías, F. Vaca, J.P. Bolivar, Water Research 47, 6269-6279 (2013) 